\title{
Faktor - Faktor yang Mempengaruhi Luas Pengungkapan Corporate Social Responsibility
}

\author{
Komang Rimba Rainugraha Tista ${ }^{1}$ \\ Fakultas Ekonomi dan Bisnis \\ Universitas Udayana, Indonesia
}

\author{
I G. A. M. Asri Dwija Putri2 \\ Fakultas Ekonomi dan Bisnis \\ Universitas Udayana, Indonesia
}

Surel : rimbatista74@gmail.com

\section{ABSTRAK}

Pengungkapan tanggung jawab sosial perusahaan menjadi penting bagi para stakeholder untuk melihat apakah perusahaan telah bertanggungjawab atas dampak negatif yang timbul dari aktivitasnya. Penelitian ini dilakukan untuk menguji secara empiris pengaruh profitabilitas, kapitalisasi pasar, dan kepemilikan saham publik pada luas pengungkapan corporate social responsibility perusahaan perkebunan yang terdaftar di BEI 2014-2018. Penelitian ini dilakukan pada seluruh perusahaan perkebunan yang terdaftar di BEI 2014-2018. Jumlah pengamatan yang diperoleh sebanyak 54 dengan metode purposive sampling. Teknik analisis yang digunakan yaitu analisis regresi linier berganda. Berdasarkan hasil analisis ditemukan bahwa profitabilitas berpengaruh positif pada luas pengungkapan CSR, kapitalisasi pasar berpengaruh positif pada luas pengungkapan CSR, dan kepemilikan saham publik tidak berpengaruh pada luas pengungkapan CSR.

Kata Kunci: Profitabilitas; Kapitalisasi Pasar; Kepemilikan Saham Publik; Pengungkapan Corporate Social Responsibility.

\section{Factors That Influence The Extent Of Corporate Social Responsibility Disclosure}

\section{ABSTRACT}

Disclosure of corporate social responsibility becomes important for stakeholders to see whether the company has been responsible for the negative impacts arising from its activities. This research was conducted to empirically examine the effect of profitability, market capitalization, and public share ownership on the broad disclosure of corporate social responsibility of plantation companies listed on the Indonesia Stock Exchange 2014-2018. This research was conducted on all plantation companies listed on the Indonesia Stock Exchange 2014-2018. The number of observations obtained was 54 with a purposive sampling method. The analysis technique used is multiple linear regression analysis. Based on the results of the analysis found that profitability has a positive effect on CSR disclosure, market capitalization has a positive effect on CSR disclosure, and public share ownership has no effect on CSR disclosure.

Keywords: $\quad$ Profitability; Market Capitalization; Public Share Ownership; Corporate Social Responsibility Disclosure.

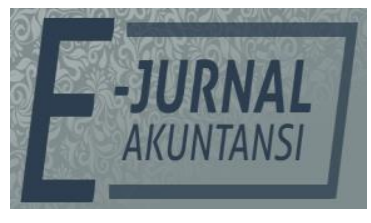

e-ISSN 2302-8556

Vol. 30 No. 11

Denpasar, Nopember 2020

Hal. 2737-2752

DOI:

10.24843/EJA.2020.v30.i11.p03

PENGUTIPAN:

Tista, K.R.R., \& Putri, I

G.A.M. (2020). Faktor -

Faktor yang Mempengaruhi

Luas Pengungkapan

Corporate Social Responsibility.

E-Jurnal Akuntansi, 30(11),

$2737-2752$

RIWAYAT ARTIKEL:

Artikel Masuk:

25 Juni 2020

Artikel Diterima:

8 Agustus 2020

Artikel dapat diakses : https://ojs.unud.ac.id/index.php/Akuntansi/index 


\section{PENDAHULUAN}

Corporate Social Responsibility (CSR) adalah suatu tindakan atau konsep dalam bentuk tanggung jawab yang dilakukan oleh perusahaan terhadap pihak yang terkena dampak dari setiap aktivitas yang dilakukan. Konsep mengenai CSR berakar dari sebuah gagasan, dimana perusahaan tidak lagi dihadapkan pada tanggung jawab yang berpijak pada single bottom line, yaitu nilai perusahaan yang direfleksikan dalam kondisi keuangannya saja, tetapi tanggung jawab perusahaan harus berpijak pada triple bottom lines, yaitu memperhatikan masalah lingkungan dan sosial (Budiman, 2015). Sehingga tanggung jawab perusahaan tidak terbatas hanya kepada pemilik atau pemegang saham saja, melainkan juga terhadap para stakeholder yang juga terkena dampak dari keberadaan perusahaan. Sudah menjadi fakta bagaimana resistensi masyarakat sekitar, di berbagai tempat dan waktu muncul ke permukaan terhadap perusahaan yang dianggap tidak memperhatikan aspek-aspek sosial, ekonomi dan lingkungan hidupnya (Rokhlinasari, 2015). Melalui keberadaan kontrol dari pihak stakeholder kepada perusahaan, diharapkan dapat memberikan kontribusi dunia usaha yang terukur sistematis dalam partisipasinya meningkatkan kesejahteraan masyarakat (Felicia \& Rasmini, 2015).

Kesadaran masyarakat yang semakin meningkat akan pentingnya peran perusahaan dalam lingkungan sosial menjadikan masyarakat membutuhkan informasi mengenai sejauh mana perusahaan telah melaksanakan aktivitas sosialnya. Melalui pengungkapan informasi tersebut masyarakat dapat memastikan bahwa hak-hak mereka telah terpenuhi (Fariati \& Segoro, 2013). Dalam teori stakeholder, manajemen perusahaan akan memenuhi harapan para stakeholder karena keberadaan suatu perusahaan sangat dipengaruhi oleh dukungan yang diberikan oleh stakeholder kepada perusahaan tersebut, maka untuk memenuhinya perusahaan akan meningkatkan perhatian terhadap aktivitas sosial lingkungannya serta akan memilih untuk secara sukarela mengungkapkan informasi tentang kinerja lingkungan dan sosial sebagai wujud akuntabilitas perusahaan kepada stakeholder. Selain itu, aktivitas dan pengungkapan informasi tanggung jawab sosial juga berguna bagi perusahaan untuk mendapatkan legitimasi masyarakat. Melalui pengungkapan CSR secara berkelanjutan, perusahaan akan menjamin operasi mereka berada dalam batas dan norma yang berlaku di masyarakat. Hal ini menjadikan informasi terkait tanggung jawab sosial perusahaan menjadi salah satu wujud akuntabilitas perusahaan kepada para stakeholder serta sebagai sarana memperoleh legitimasi atas aktivitasnya di lingkungan masyarakat sehingga perusahaan dapat menjaga keberlanjutannya (Indraswari \& Mimba, 2017).

Pelaksanaan dan pengungkapan CSR di Indonesia sudah diatur dengan menerbitkan berbagai macam regulasi, diantaranya yaitu Undang-Undang (UU) No. 40 Tahun 2007 tentang Perseroan Terbatas, PP No. 47 Tahun 2012 tentang Tanggungjawab Sosial dan Lingkungan Perseroan Terbatas dan Undang-Undang No. 25 Tahun 2007 tentang Penanaman Modal. UU No. 40 Tahun 2007 tentang Perseroan Terbatas mengatur setiap perusahaan yang menjalankan usahanya dibidang dan/atau bersangkutan dengan sumber daya alam wajib menjalankan tanggung jawab sosial dan lingkungan serta pelaksanaannya harus dilaporkan dalam laporan tahunan perusahaan. Pengungkapan CSR juga telah terakomodasi dalam Pernyataan Standar Akuntansi Keuangan (PSAK) No.1 Tahun 2013 tentang 
Penyajian Laporan Keuangan. Berdasarkan PSAK No.1 Tahun 2013 tentang Penyajian Laporan Keuangan paragraf 12 dinyatakan bahwa: "Perusahaan dapat pula menyajikan laporan tambahan seperti laporan mengenai lingkungan hidup dan laporan nilai tambah (value added statement), khususnya bagi industri dimana faktor-faktor lingkungan hidup memegang peranan penting dan bagi industri yang menganggap pegawai sebagai kelompok pengguna laporan yang memegang peranan penting" (Kusumawardani \& Sudana, 2017).

Regulasi yang ada memang sudah mewajibkan perusahaan untuk melakukan pengungkapan tanggung jawab sosial perusahaan, sehingga pengungkapan tanggung jawab sosial perusahaan di Indonesia sudah termasuk dalam pengungkapan wajib (mandatory disclosure). Namun demikian, belum adanya standar pelaporan yang dapat memberikan pedoman secara khusus mengenai informasi apa saja yang harus dilaporkan serta bagaimana kebijakan pelaporannya, menyebabkan luas pengungkapan CSR di Indonesia masih bersifat sukarela (voluntary disclosure). Pengungkapan CSR yang masih bersifat sukarela ini kemudian menyebabkan luas pengungkapan informasi tanggung jawab sosial masih bergantung pada kebijakan dari perusahaan masing-masing dan berakibat pada masih bervariasinya luas pengungkapan CSR pada tiap-tiap perusahaan.

Faktor-faktor yang diduga dapat mempengaruhi luas pengungkapan CSR adalah profitabilitas, kapitalisasi pasar, dan kepemilikan saham publik. Berbagai penelitian terdahulu terkait beberapa faktor yang mempengaruhi pengungkapan tanggung jawab sosial, diantaranya penelitian Yanti \& Budiasih (2016) dan Indraswari \& Astika (2014) menyatakan bahwa terdapat hubungan yang positif antara profitabilitas dan tingkat pengungkapan tanggung jawab sosial perusahaan. Profitabilitas merupakan faktor yang memberikan kebebasan dan fleksibilitas kepada manajemen untuk mengungkapkan pertanggungjawaban sosial kepada pemegang saham (Hackston \& Milne, 1996). Perusahaan dengan tingkat profitabilitas tinggi akan memberikan informasi pengungkapan CSR yang lebih rinci sebagai wujud akuntabilitas pengelolaan perusahaan kepada stakeholder, karena dengan profitabilitas yang tinggi perusahaan dapat mengalokasikan biaya yang lebih besar untuk melaksanakan dan mengungkapkan CSR. Penelitian terdahulu yang dilakukan oleh Ebiringa., et al (2013), Felicia \& Rasmini (2015), Gunawan et al., (2018) dan Hapsoro \& Sulistyarini (2019) menemukan hasil bahwa profitabilitas berpengaruh positif pada pengungkapan CSR. Sedangkan hasil penelitian yang berbeda ditemukan pada penelitian Deitiana (2015), Kusumawardani \& Sudana (2017), Wulandari \& Sudana (2018) yang menyatakan bahwa tidak adanya pengaruh profitabilitas terhadap pengungkapan CSR.

Faktor lain yang dapat mempengaruhi luas pengungkapan CSR adalah kapitalisasi pasar. Kapitalisasi pasar menunjukkan harga keseluruhan dari saham yang beredar di pasar. Perusahaan dengan kapitalisasi pasar yang besar akan lebih banyak mendapatkan perhatian dan memiliki keterkaitan yang lebih luas terhadap masyarakat dan stakeholder lainnya, sehingga menuntut perusahaan untuk melakukan pengungkapan CSR secara lebih luas (Indraswari \& Mimba, 2017). Penelitian mengenai pengaruh kapitalisasi pasar pada luas pengungkapan CSR mendapatkan hasil yang berbeda. Pada penelitian Sufian (2012) dan Oktavila (2019) mendapatkan hasil bahwa kapitalisasi pasar berpengaruh positif terhadap 
luas pengungkapan CSR. Sedangkan hasil yang berbeda ditemukan pada penelitian Deitiana (2015) yang menyatakan bahwa kapitalisasi pasar tidak berpengaruh terhadap pengungkapan CSR.

Selain kapitalisasi pasar, faktor lainnya yang dapat mempengaruhi luas pengungkapan CSR adalah kepemilikan saham publik. Kepemilikan saham publik merupakan tingkat kepemilikan perusahaan oleh masyarakat publik (Rindawati \& Asyik, 2015). Melalui kepemilikan saham publik, diharapkan semakin terciptanya transparansi informasi yaitu dengan melaporkan keadaan perusahaan dan semua aktivitasnya kepada publik, sehingga perusahaan akan melakukan pengungkapan CSR yang lebih rinci (Nur \& Priantinah, 2012). Penelitian mengenai pengaruh kepemilikan saham publik pada luas pengungkapan CSR mendapatkan hasil yang berbeda, dimana dalam penelitian Sugiarto \& Mas'ud (2016), Evandini \& Darsono (2014), Rahayu \& Anisyukurlillah (2015) dan Gunawan et al., (2018) menunjukkan hasil bahwa kepemilikan saham publik berpengaruh positif terhadap pengungkapan CSR. Sedangkan hasil penelitian Santoso et al., (2017), Andriana \& Anggara (2019) menemukan hasil bahwa kepemilikan saham publik tidak berpengaruh terhadap pengungkapan CSR.

Penelitian ini dilakukan pada perusahaan perkebunan yang terdaftar di BEI tahun 2014-2018. Pemilihan sampel penelitian ini dikarenakan perusahaan perkebunan merupakan bidang usaha yang berkembang pesat saat ini, namun disisi lain memiliki implikasi besar atas dampak dari operasi perusaahaan mereka yang dapat merugikan masyarakat dan lingkungan. Hal ini dikarenakan, perusahaan perkebunan sangat bergantung pada penggunaan lahan yang tidak jarang diperoleh melalui penebangan dan pembakaran hutan yang tentunya berdampak negatif terhadap masyarakat dan lingkungan. Greenpeace (2018) menyatakan bahwa sejak tahun 2015 sebanyak 130.000 hektar kawasan hutan hancur akibat deforestasi. Industri sektor perkebunan kelapa sawit dan bubur kayu menjadi pemicu kerusakan hutan ini. Adapun kasus kerusakan lingkungan oleh perusahaan perkebunan yaitu kebakaran hutan dan lahan oleh anak perusahaan Sampoerna Agro Tbk yaitu PT National Sago Prima pada tahun 2014 seluas 3.000 hektar di Riau (www.detik.com). Kasus lainnya yaitu kebakaran hutan dan lahan oleh PT Jatim Jaya Perkasa seluas 1.000 hektare, PT Waringin Agro Jaya seluas 1.802 hektar dan PT Palmina Utama seluas 511 hektare lahan. Ketiga perusahaan yang terjerat kasus ini dinyatakan bersalah dan harus membayar ganti rugi serta melakukan pemulihan lingkungan pada tahun 2018 (www.cnnindonesia.com). Fenomena dan kasus yang ada semakin menunjukkan eratnya keterkaitan perusahaan perkebunan terhadap isu-isu kebakaran hutan dan lahan yang terjadi saat ini. Oleh karena itu, pengungkapan tanggung jawab sosial perusahaan kemudian menjadi penting bagi para stakeholder untuk melihat apakah perusahaan telah bertanggungjawab atas dampak negatif yang timbul dari aktivitasnya terhadap lingkungan dan masyarakat.

Landasan teori untuk menjelaskan penelitian ini adalah teori stakeholder dan teori legitimasi, dimana teori stakeholder mengungkapkan bahwa perusahaan bukanlah entitas yang hanya beroperasi untuk kepentingannya sendiri namun juga harus memberikan manfaat bagi stakeholder (pemegang saham, kreditor, 
konsumen, supplier, pemerintah, masyarakat, analis dan pihak lain) (Ghozali \& Chariri, 2007 2014:438). Teori ini mengasumsikan bahwa eksistensi perusahaan ditentukan oleh dukungan para stakeholder, sehingga aktivitas yang seharusnya dilakukan perusahaan adalah untuk mencari dukungan tersebut.

Salah satu wujud akuntabilitas perusahaan terhadap stakeholder adalah melakukan pengungkapan kegiatan tanggung jawab sosial yang dilakukan perusahaan. Pengungkapan tanggung jawab sosial perusahaan menjadi sarana yang baik bagi perusahaan untuk menegosiasikan hubungan dengan para stakeholder (Nur \& Priantinah 2012). Pengungkapan CSR sangat penting bagi stakeholder karena para stakeholder perlu mengetahui dan mengevaluasi sejauh mana perusahaan melaksanakan perannya sesuai dengan keinginan stakeholder, sehingga menuntut akuntabilitas perusahaan atas kegiatan yang telah dilakukan perusahaan (Riswari \& Cahyonowati, 2012). Semakin baik pengungkapan CSR yang dilakukan oleh perusahaan maka stakeholder akan semakin memberikan dukungan penuh kepada perusahaan atas segala aktivitasnya yang bertujuan untuk meningkatkan kinerja dan mencapai laba yang diharapkan perusahaan (Lindawati \& Puspita, 2015).

Teori legitimasi menyatakan bahwa organisasi adalah bagian dari masyarakat sehingga harus memperhatikan norma-norma sosial masyarakat karena kesesuaian dengan norma sosial dapat membuat perusahaan semakin legitimate. Kedudukan perusahaan sebagai bagian dari masyarakat ditunjukkan melalui proses produksi yang dapat mempengaruhi masyarakat dan lingkungan disekitarnya. Ketika perusahaan gagal dalam menyesuaikan diri terhadap norma ataupun adat yang diterima oleh masyarakat, hal ini akan mengancam legitimasi perusahaan yang pada akhirnya akan mengancam kelangsungan hidup perusahaan. Dalam upaya memperoleh legitimasi, perusahaan sangat membutuhkan sebuah aktivitas CSR yang dipublikasikan. Perusahaan tersebut akan senantiasa terdorong untuk mengungkapkan segala aktivitas tanggung jawab sosial yang mereka lakukan dalam sebuah laporan yang dipublikasikan. Pengungkapan CSR digunakan untuk melegitimasi aktivitas perusahaan dimata masyarakat karena mengambarkan kesan langsung tanggung jawab sosial dan lingkungan perusahaan. Selain itu, pengungkapan CSR juga menunjukkan tingkat kepatuhan suatu perusahaan (Branco \& Rodrigues, 2008).

Kemampuan perusahaan untuk menghasilkan keuntungan dalam kurun periode tertentu disebut sebagai profitabilitas perusahaan. Hackston \& Milne (1996) menyatakan bahwa profitabilitas merupakan faktor yang memberikan kebebasan dan fleksibilitas kepada manajemen untuk mengungkapkan pertanggungjawaban sosial kepada pemegang saham. Perusahaan dengan profitabilitas tinggi akan lebih rinci dalam melakukan pengungkapan CSR, karena manajemen perusahaan akan memiliki kesempatan lebih untuk melaksanakan dan mengungkapkan CSR akibat adanya alokasi dana yang lebih banyak untuk kegiatan CSR. Melalui Pengungkapan CSR yang lebih rinci, diharapkan dapat memenuhi harapan masyarakat dan para stakeholder lainnya bahwa dengan profitabilitas yang tinggi, perusahaan mampu mengalokasikan biaya yang lebih besar untuk melaksanakan dan mengungkapkan tanggung jawab sosial perusahaan. 
Dalam penelitiannya, Mudjiyanti \& Maulani (2017) menyatakan bahwa semakin tinggi tingkat profitabilitas maka semakin tinggi pula tingkat pengungkapan tanggung jawab sosial perusahaan karena perusahaan dengan profitabilitas yang tinggi dapat mengatasi timbulnya biaya-biaya atas pengungkapan tanggung jawab sosial tersebut. Hal ini sejalan dengan penelitian yang dilakukan oleh Ebiringa et al., (2013), Indraswari \& Astika (2014), Felicia \& Rasmini (2015), Yanti \& Budiasih (2016), Gunawan et al., (2018) dan Sulistyarini \& Hapsoro (2019) yang menyatakan bahwa profitabilitas berpengaruh positif pada pengungkapan tanggung jawab sosial perusahaan

$\mathrm{H}_{1}$ : Profitabilitas berpengaruh positif pada luas pengungkapan CSR.

Besar atau tidaknya perusahaan di bursa saham dapat ditunjukkan oleh nilai kapitalisasi pasar perusahaan (Rifqiawan, 2015). Perusahaan besar yang digambarkan melalui nilai kapitalisasi pasar yang tinggi akan menyebabkan masyarakat dan stakeholder lainnya menjadi lebih terkait dan memperhatikan perusahaan. Perusahaan besar juga akan mengalami tekanan yang jauh lebih kuat untuk memenuhi berbagai peraturan dan ketentuan, sehingga perusahaan diharapkan dapat menunjukkan akuntabilitas secara lebih luas kepada seluruh pihak yang berkepentingan terhadap perusahaan melalui pengungkapan informasi tanggung jawab sosial yang lebih rinci (Indraswari \& Mimba, 2017)

Rahayu \& Rahayu (2013) menyatakan bahwa kapitalisasi pasar merupakan istilah bisnis yang menunjukkan harga keseluruhan dari sebuah saham perusahaan. Perusahaan dengan harga saham yang tinggi pada umumnya semakin diminati dan mendapatkan perhatian para investor. Investor membutuhkan informasi seluas-luasnya mengenai perusahaan untuk dapat memperkecil tingkat ketidakpastian yang akan dihadapi mengenai masa depan perusahaan, sehingga perusahaan akan termotivasi untuk melakukan pengungkapan yang lebih luas salah satunya yaitu pengungkapan informasi tanggung jawab sosial perusahaan. Melalui pengungkapan informasi tersebut diharapkan perusahaan akan memperoleh legitimasi dari masyarakat serta stakeholder lainnya yang akan berdampak pada kelangsungan hidup perusahaan (Rahayu \& Rahayu, 2013). Pernyataan ini sejalan dengan hasil penelitian yang dilakukan oleh Sufian (2012) dan Oktavila (2019) yang menyatakan bahwa kapitalisasi pasar berpengaruh pada pengungkapan CSR.

$\mathrm{H}_{2}$ : Kapitalisasi pasar berpangaruh positif pada luas pengungkapan CSR.

Kepemilikan saham publik adalah jumlah saham yang dimiliki oleh masyarakat umum atau publik yang terdapat pada perusahaan. Adanya proporsi kepemilikan saham publik menyebabkan kondisi dimana publik memiliki hak pada perusahaan terkait pemenuhan kebutuhan informasi dan perusahaan memiliki kewajiban untuk melaporkan atau memberikan informasi mengenai keadaan perusahaan, sehingga perusahaan yang memiliki kepemilikan saham oleh publik yang tinggi akan lebih termotivasi untuk lebih melakukan pengungkapkan aktivitas tanggung jawab sosial sebagai wujud akuntabilitas perusahaan kepada publik (Evandini \& Darsono, 2014).

Teori stakeholder menjelaskan bahwa perusahaan tidak dapat dipandang sebagai entitas yang terpisah dengan berbagai pihak yang berkepentingan. Adanya rasio kepemilikan saham publik yang tinggi diprediksi perusahaan akan melakukan pengungkapan tanggung jawab sosial yang lebih luas, hal ini 
dikaitkan dengan tekanan publik sebagai pihak yang berkepentingan terhadap perusahaan, agar perusahaan lebih memperhatikan akuntabilitas serta tanggung jawabnya terhadap masyarakat (Wakidi \& Siregar, 2011). Maka, semakin besar proporsi kepemilikan saham perusahaan oleh publik, perusahaan akan cenderung melakukan pengungkapan yang lebih luas. Pernyataan ini didukung oleh hasil penelitian yang dilakukan oleh Sugiarto \& Mas'ud (2016), Rahayu \& Anisyukurlillah (2015) yang menyatakan bahwa kepemilikan saham publik berpengaruh pada pengungkapan CSR.

$\mathrm{H}_{3}$ : Kepemilikan saham publik berpengaruh positif pada luas pengungkapan CSR.

\section{METODE PENELITIAN}

Penelitian ini merupakan penelitian kuantitatif yang berbentuk asosiatif, desain penelitian yang digunakan pada penelitian ini digambarkan pada Gambar 1, sebagai berikut.

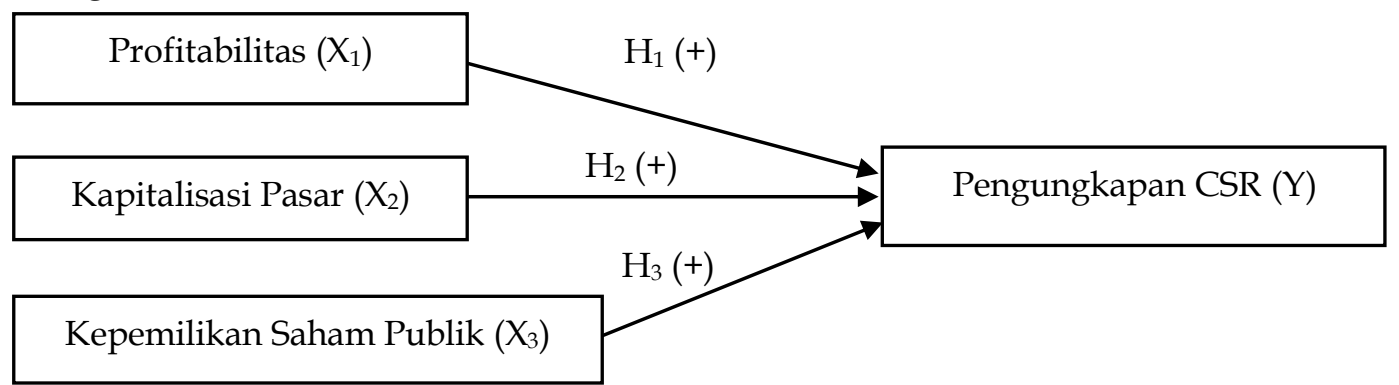

\section{Gambar 1. Desain Penelitian}

Sumber: Data Penelitian, 2020

Penelitian ini dilakukan pada perusahaan perkebunan yang terdaftar di Bursa Efek Indonesia (BEI) tahun 2014-2018 dengan mengakses website resmi Bursa Efek Indonesia www.idx.co.id. Objek penelitian dalam penelitian ini adalah luas pengungkapan corporate social responsibility dalam annual report atau sustainability report perusahaan perkebunan yang terdaftar di BEI tahun 2014-2018. Populasi dalam penelitian ini adalah seluruh perusahaan perkebunan yang terdaftar di BEI tahun 2014-2018. Teknik pengambilan sampel yang digunakan dalam penelitian ini adalah non probability sampling, yaitu purposive sampling. Adapun kriteria pemilihan sampel, yaitu perusahaan perkebunan yang terdaftar di Bursa Efek Indonesia selama periode 2014-2018; Perusahaan perkebunan yang melaporkan pertanggungjawaban sosial (CSR) dalam laporan tahunan atau laporan sustainability; Perusahaan yang tidak mengalami kerugian selama periode pengamatan; Perusahaan yang memiliki data laporan tahunan secara lengkap mengenai variabel penelitian seperti data yang digunakan untuk menghitung nilai profitabilitas, kapitalisasi pasar dan kepemilikan saham publik.

Pada penelitian ini variabel yang diuji yaitu variabel dependen berupa luas pengungkapan CSR $(Y)$, variabel independennya meliputi profitabilitas $\left(\mathrm{X}_{1}\right)$, kapitalisasi pasar $\left(X_{2}\right)$, dan kepemilikan saham publik $\left(X_{3}\right)$. Pengungkapan Corporate Social Responsibility merupakan pengungkapan yang dilakukan perusahaan sebagai wujud tanggung jawab perusahaan terhadap lingkungan sosial melalui aktivitas-aktivitas yang dilakukan perusahaan. Luas pengungkapan 
CSR dalam penelitian ini diukur dengan menggunakan indeks GRI (Global Reporting Initiative) versi G4 yaitu sebanyak 91 item. Total pengungkapan sejumlah 91 item meliputi indikator pelaporan ekonomi, lingkungan, ketenagakerjaan, hak asasi manusia, masyarakat dan tanggung jawab atas produk. Peneliti melakukan content analysis dan scoring terhadap konten yang sesuai dengan kriteria kelengkapan yang ditentukan GRI. G4 pada laporan perusahaan baik itu laporan tahunan atau laporan sustainability. Pendekatan untuk menghitung luas pengungkapan CSR pada dasarnya menggunakan pendekatan dikotomi, yaitu setiap item CSR diberi skor 1 jika diungkapkan, dan skor 0 jika tidak diungkapkan (Haniffa \& Cooke, 2005).

Rumus untuk menghitung Corporate Social Responsibility Disclosure Indeks (CSRDI) adalah sebagai berikut.

CSRDI $=\frac{\text { Jumlah item informasi CSR yang diungkapkan }}{91 \text { item CSR versi GRI. G4 }}$

Profitabilitas merupakan suatu indikator kinerja manajemen dalam mengelola kekayaan perusahaan, ditunjukkan dari besarnya laba yang diperoleh (Andriana \& Anggara, 2019). Rasio profitabilitas berguna untuk mengukur kemampuan perusahaan dalam memperoleh laba, baik dalam hubungannya dengan penjualan, aset, maupun modal sendiri. Profitabilitas dalam penelitian ini diukur dengan menggunakan nilai ROA (Return on Asset). Rasio ini berguna bagi manajemen dalam menentukan langkah apa yang seharusnya dilakukan, karena ROA dapat digunakan untuk memprediksi keuangan perusahaan (Jewell \& Mankin, 2011). Nilai profitabilitas dapat diukur dengan rumus (Prakasa \& Astika, 2017).

ROA $=\frac{\text { Laba bersih setelah pajak }}{\text { Total aset }} \times 100 \%$

Kapitalisasi pasar mencerminkan total nilai pasar dari perusahaan, yang dihitung dengan mengalikan harga saham di bursa saham dengan jumlah saham yang beredar (Deitiana, 2015). Pengukuran variabel kapitalisasi pasar dirumuskan sebagai berikut:

Kapitalisasi pasar $=$ Harga pasar saham $\times$ jumlah saham yang bereda.... (3)

Kepemilikan saham oleh publik menggambarkan tingkat kepemilikan perusahaan oleh masyarakat publik. Besarnya saham publik atau masyarakat diukur melalui rasio dari jumlah kepemilikan lembar saham yang dimiliki publik terhadap total lembar saham perusahaan. Nilai kepemilikan saham publik dapat diukur dengan rumus.

Kepemilikan Saham Publik $=\frac{\text { Jumlah saham yang dimiliki publik }}{\text { Total lembar saham perusahaan }}$

Pada penelitian ini teknik analisis data yang digunakan adalah analisis regresi linier berganda dengan menggunakan Statistical Package for the Social Sciences (SPSS) untuk mengolah data. Sebelum dilakukan analisis regresi linier berganda terlebih dahulu dilakukan uji asumsi klasik yang terdiri dari uji normalitas, uji multikolinearitas, uji autokorelasi, dan uji heterokedasitas.

Analisis regresi linier berganda digunakan untuk mengetahui pengaruh dari setiap variabel bebas pada variabel terikat, yang dapat dinyatakan sebagai bentuk model matematis. Persamaan regresi yang digunakan adalah sebagai berikut.

$Y=\alpha+\beta 1 X 1+\beta 2 X 2+\beta 3 X 3+\varepsilon$ 


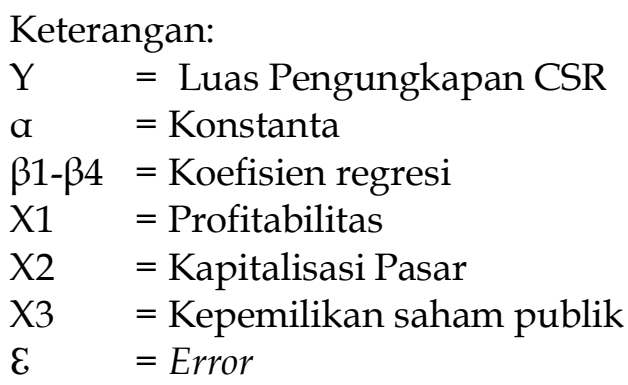

\section{HASIL DAN PEMBAHASAN}

Analisis statistik deskriptif dilakukan untuk memberikan gambaran data yang dilihat dari nilai maksimum, minimum, rata - rata (mean) dan standar deviasi dari setiap variabel dalam penelitian, yaitu profitabilitas, kapitalisasi pasar, dan kepemilikan saham publik. Adapun hasil dari analisis statistik deskriptif dapat dilihat pada Tabel 1 sebagai berikut.

Tabel 1. Hasil Analisis Statistik Deskriptif

\begin{tabular}{lllllc}
\hline & N & Minimum & Maximum & Mean & $\begin{array}{c}\text { Std. } \\
\text { Deviation }\end{array}$ \\
\hline CSRDI $(\mathrm{Y})$ & 54 & 0,0659 & 0,7143 & 0,328246 & 0,1346222 \\
ROA $\left(\mathrm{X}_{1}\right)$ & 54 & 0,0001 & 0,1412 & 0,052156 & 0,0331279 \\
Kapitalisasi Pasar $\left(\mathrm{X}_{2}\right)$ & 54 & 26,3262 & 31,2735 & 29,324831 & 1,1146981 \\
KSP $\left(\mathrm{X}_{3}\right)$ & 54 & 0,0280 & 0,4867 & 0,249667 & 0,1196654 \\
Valid N (listwise) & 54 & & & & \\
\hline
\end{tabular}

Sumber: Data Penelitian, 2020

Variabel Y yang diproksikan dengan CSDI memiliki nilai minimum sebesar 0.0659 yaitu pengungkapan CSR pada PT Gozco Plantation Tbk tahun 2015 dan PT Multi Agro Gemilang Plantation Tbk tahun 2014, sedangkan nilai maksimum pengungkapan CSR sebesar 0,7143 yaitu pengungkapan CSR dari perusahaan Astra Agro Lestari Tbk tahun 2016. Nilai mean (rata-rata) sebesar 0,328246 atau sebanyak 31 item pengungkapan CSR dari 91 indikator pengungkapan CSR berdasarkan GRI G4 dengan standar deviasi pengungkapan CSR sebesar 0,1346222. Variabel profitabilitas yang diproksikan dengan ROA memiliki nilai minimum sebesar 0,0001 dimiliki oleh PT Multi Agro Gemilang Tbk tahun 2014, sedangkan nilai maksimum sebesar 0,1412 dimiliki oleh PT Astra Agro Lestari Tbk tahun 2015. Nilai mean (rata-rata) profitabilitas sebesar 0,052156 dengan standar deviasi sebesar 0,0331279. Variabel kapitalisasi pasar memiliki nilai minimum sebesar 26,3262 dimiliki oleh PT Golden Plantation Tbk tahun 2017, sedangkan nilai maksimum sebesar 31,2735 dimiliki oleh PT Astra Agro Lestari Tbk tahun 2014. Nilai mean (rata-rata) kapitalisasi pasar sebesar 29,3248 dengan standar deviasi sebesar 1,1146981. Variabel kepemilikan saham publik memiliki nilai minimum sebesar 0,0280 dimiliki oleh PT SMART Tbk tahun 2014 dan 2015, sedangkan nilai maksimum sebesar 0,4867 dimiliki oleh PT Tunas Baru Lampung Tbk tahun 2016. Nilai mean (rata-rata) kepemilikan saham publik sebesar 0,249667 dengan standar deviasi sebesar 0,1196654.

Uji asumsi klasik diperlukan agar model regresi yang dijadikan alat estimasi tidak bias. Uji asumsi klasik yang dilakukan adalah uji normalitas, 
autokorelasi, multikolinearitas dan heteroskedastisitas. Hasil uji asumsi klasik dapat dilihat pada Tabel 2.

Tabel 2. Hasil Uji Asumsi Klasik

\begin{tabular}{cccccc}
\hline \multirow{2}{*}{ Keterangan } & $\begin{array}{c}\text { Uji } \\
\text { Normalitas }\end{array}$ & \multicolumn{2}{c}{ Uultikolononieritas } & Heteroskedastisitas & $\begin{array}{c}\text { Uji } \\
\text { Autokorelasi }\end{array}$ \\
\cline { 2 - 6 } & $\begin{array}{c}\text { Asymp. Sig. } \\
\text { (2- tailed) }\end{array}$ & Tolerance & VIF & Sig. & $\begin{array}{c}\text { Asymp. Sig. } \\
\text { (2- tailed) }\end{array}$ \\
\hline ROA $\left(\mathrm{X}_{1}\right)$ & & 0,965 & 1,037 & 0,992 & \\
$\begin{array}{c}\text { Kapitalisasi } \\
\text { Pasar }\left(\mathrm{X}_{2}\right)\end{array}$ & & 0,964 & 1,038 & 0,052 & \\
$\begin{array}{c}\text { Kepemilikan } \\
\text { saham } \\
\text { publik }\left(\mathrm{X}_{3}\right)\end{array}$ & & 0,999 & 1,001 & 0,935 & \\
\hline
\end{tabular}

Sumber: Data Penelitian, 2020

Uji normalitas dengan kolmogorov smirnov menghasilkan nilai Asymp. Sig. (2-tailed) sebesar 0,061 lebih besar dari 0.05. Hal ini menunjukkan bahwa data pada model regresi yang digunakan dalam penelitian ini telah berdistribusi normal. Hasil uji multikolonieritas menunjukkan seluruh variabel bebas yang diuji yaitu profitabilitas, kapitalisasi pasar, dan dan kepemilikan saham publik memiliki nilai tolerance lebih besar dari 0,1 . Sedangkan nilai VIF yang diperoleh lebih kecil dari 10 maka dapat disimpulkan bahwa model telah bebas dari masalah multikolinearitas. Uji heterokedastisitas menghasilkan nilai sig. tiap variabel lebih besar dari tingkat signifikansi 0,05 yang menunjukkan bahwa model regresi yang digunakan dalam penelitian ini bebas dari gejala heteroskedastisitas. Berdasarkan hasil uji autokorelasi dengan run tes, nilai Asymp. Sig. (2-tailed) sebesar 0,354 > 0,05 maka dapat disimpulkan tidak terjadi gejala autokorelasi.

Analisis regresi linier berganda digunakan untuk mengetahui dan memperoleh gambaran mengenai pengaruh variabel independen yang mana dalam penelitian ini antara lain profitabilitas $\left(X_{1}\right)$, kapitalisasi pasar $\left(X_{2}\right)$, kepemilikan saham publik $\left(X_{3}\right)$ pada variabel dependen yaitu luas pengungkapan CSR (Y). Hasil analisis regresi linier berganda dapat dilihat pada Tabel 3, berikut. Tabel 3. Hasil Analisis Regresi Linier Berganda

\begin{tabular}{llll}
\hline \multirow{2}{*}{ Variabel } & \multicolumn{2}{l}{ Unstandardized Coefficients } & \multirow{2}{*}{ Sig. } \\
& $\mathrm{B}$ & Std. Error & 0,991 \\
\hline Constant) & $-0,001$ & 0,091 & 0,046 \\
Profitabilitas $\left(\mathrm{X}_{1}\right)$ & 0,209 & 0,102 & 0,000 \\
Kapitalisasi Pasar $\left(\mathrm{X}_{2}\right)$ & 0,587 & 0,092 & 0,362 \\
Kepemilikan Saham Publik $\left(\mathrm{X}_{3}\right)$ & 0,083 & 0,090 & \\
Adjusted R Square & 0,484 & & \\
$\mathrm{~F}$ & 170,566 & & \\
Sig. & $0,000^{\mathrm{b}}$ & & \\
\hline
\end{tabular}

Sumber: Data Penelitian, 2020

Berdasarkan hasil analisis regresi linier berganda pada Tabel 2, diperoleh persamaan regresi sebagai berikut.

$$
Y=-0,001+0,209 X_{1}+0,587 X_{2}+0,083 X_{3}+\varepsilon
$$


Nilai konstanta sebesar -0,001 memiliki arti apabila variabel profitabilitas, kapitalisasi pasar dan kepemilikan saham publik bernilai sama dengan nol maka luas pengungkapan CSR adalah sebesar $-0,001$.

Nilai koefisien regresi profitabilitas $\left(X_{1}\right)$ sebesar 0,209 memiliki arti apabila profitabilitas meningkat satu satuan, maka luas pengungkapan CSR akan mengalami peningkatan sebesar 0,209 satuan dengan asumsi variabel lainnya konstan.

Nilai koefisien regresi kapitalisasi pasar $\left(\mathrm{X}_{2}\right)$ sebesar 0,587 memiliki arti apabila kapitalisasi pasar meningkat satu satuan, maka luas pengungkapan CSR akan mengalami peningkatan sebesar 0,587 satuan dengan asumsi variabel lainnya konstan.

Nilai koefisien regresi kepemilikan saham publik $\left(X_{3}\right)$ sebesar 0,083 memiliki arti apabila kepemilikan saham publik meningkat satu satuan, maka luas pengungkapan CSR akan meningkat sebesar 0,083 satuan dengan asumsi variabel lainnya konstan.

Uji kelayakan model (Uji F) bertujuan untuk mengidentifikasi model regresi yang diestimasi layak atau tidak layak digunakan untuk menjelaskan pengaruh variabel-variabel independen terhadap variabel dependen dan untuk mengatahui pengaruh variabel independen secara simultan terhadap variabel dependen. Apabila nilai signifikansi (Sig) $\leq$ tingkat kesalahan/error (alpha) 0,05 maka dapat dikatakan bahwa model regresi yang diestimasi layak digunakan serta terdapat pengaruh secara simultan antara variabel independen terhadap variabel dependen. Berdasarkan Tabel 2, dapat dilihat nilai $F$ hitung sebesar 170,566 dengan tingkat signifikansi sebesar 0,000 lebih kecil dari 0,05. Hasil ini menunjukkan model regresi yang terdapat dalam penelitian ini layak digunakan serta terdapat pengaruh secara simultan antara Profitabilitas $\left(X_{1}\right)$, Kapitalisasi Pasar $\left(X_{2}\right)$, dan Kepemilikan Saham Publik $\left(X_{3}\right)$ pada Luas Pengungkapan CSR $(Y)$.

Analisis koefisien determinasi bertujuan untuk mengetahui seberapa besar kemampuan variabel independen menjelaskan variabel dependen, ini dapat dilihat dari nilai $\mathrm{R}^{2}$ yaitu adjusted $\mathrm{R}^{2}$. Berdasarkan Tabel 2, nilai adjusted $\mathrm{R}^{2}$ sebesar 0,484, ini berarti sebesar 48,4\% variasi variabel Profitabilitas $\left(X_{1}\right)$, Kapitalisasi Pasar $\left(X_{2}\right)$, dan Kepemilikan Saham Publik $\left(X_{3}\right)$ dapat menjelaskan variabel Luas Pengungkapan CSR (Y). Sedangkan sisanya sebesar 51,6 \% dapat dijelaskan oleh variabel lain diluar model penelitian.

Hasil uji $\mathrm{t}$ menunjukkan bahwa variabel profitabilitas memiliki nilai koefisien regresi sebesar 0,209 dengan nilai signifikansi sebesar 0,046 lebih kecil dari 0,05. Hal ini menunjukkan bahwa profitabilitas berpengaruh pada luas pengungkapan CSR. Maka hipotesis yang menyatakan bahwa profitabilitas berpengaruh positif pada luas pengungkapan CSR $\left(\mathrm{H}_{1}\right)$ diterima.

Hasil uji $\mathrm{t}$ menunjukkan bahwa variabel kapitalisasi pasar memiliki nilai koefisien regresi sebesar 0,587 dengan nilai signifikansi sebesar 0,000 lebih kecil dari 0,05. Hal ini menunjukkan bahwa kapitalisasi pasar berpengaruh positif pada luas pengungkapan CSR. Maka hipotesis yang menyatakan bahwa kapitalisasi pasar berpengaruh positif pada luas pengungkapan CSR $\left(\mathrm{H}_{2}\right)$ diterima.

Hasil uji t menunjukkan bahwa variabel kepemilikan saham publik memiliki nilai koefisien regresi sebesar 0,083 dengan nilai signifikansi sebesar 0,362 lebih besar dari 0,05 . Hal ini menunjukkan bahwa kepemilikan saham publik tidak 
berpengaruh pada luas pengungkapan CSR. Maka hipotesis yang menyatakan bahwa kepemilikan saham publik berpengaruh positif pada luas pengungkapan $\operatorname{CSR}\left(\mathrm{H}_{3}\right)$ ditolak.

Hipotesis pertama $\left(\mathrm{H}_{1}\right)$ menyatakan bahwa profitabilitas berpengaruh positif pada pengungkapan CSR. Berdasarkan hasil penelitian menunjukkan variabel profitabilitas yang diukur dengan Return on Asset (ROA) berpengaruh positif pada pengungkapan CSR. Hasil ini menujukkan bahwa semakin besar profitabilitas (ROA) perusahaan maka semakin luas pengungkapan tanggung jawab sosial perusahaannya.

Perusahaan dengan profitabilitas tinggi akan melakukan pengungkapan CSR secara lebih luas karena profitabilitas yang tinggi membuat manajemen perusahaan memiliki kesempatan lebih untuk melaksanakan dan mengungkapkan tanggung jawab sosial perusahaannya akibat adanya alokasi dana yang lebih banyak untuk kegiatan CSR. Hasil penelitian ini mendukung teori stakeholder yang menyatakan bahwa perusahaan dengan tingkat profitabilitas yang tinggi akan mengungkapkan CSR secara lebih luas, sebagai wujud akuntabilitas perusahaan kepada para stakeholder, dengan begitu kebutuhan informasi para stakeholder perusahaan dapat terpenuhi. Hasil penelitian ini sejalan dengan penelitian terdahulu yang dilakukan oleh Ebiringa et al., (2013), Indraswari \& Astika (2014), Felicia \& Rasmini (2015), Yanti \& Budiasih (2016), Gunawan et al., (2018) dan Sulistyarini \& Hapsoro (2019) yang menyatakan bahwa profitabilitas berpengaruh positif terhadap luas pengungkapan CSR.

Hipotesis kedua $\left(\mathrm{H}_{2}\right)$ menyatakan bahwa kapitalisasi pasar berpengaruh positif pada pengungkapan CSR. Berdasarkan hasil penelitian menunjukkan variabel kapitalisasi pasar berpengaruh positif pada pengungkapan CSR. Hasil ini menujukkan bahwa semakin besar kapitalisasi pasar perusahaan maka semakin luas pengungkapan CSR perusahaan tersebut.

Perusahaan dengan kapitalisasi pasar yang besar akan melakukan pengungkapan CSR secara lebih luas. Hal ini dikarenakan, perusahaan dengan kapitalisasi pasar yang besar akan mendapatkan lebih banyak perhatian serta memiliki keterkaitan yang lebih luas terhadap para stakeholder. Perusahaan berkapitalisasi pasar besar juga lebih mendapatkan perhatian dan diminati oleh para investor, sehingga perusahaan akan termotivasi untuk melakukan pengungkapan CSR secara lebih luas. Dengan demikian penelitian ini mendukung teori stakeholder dan teori legitimasi bahwa perusahaan dengan kapitalisasi pasar yang besar akan melakukan pengungkapan CSR secara lebih luas sebagai wujud akuntabilitas terhadap para stakeholder dan dalam tujuan untuk memperoleh legitimasi masyarakat atas aktivitas perusahaan, sehingga dapat menjamin kalangsungan hidup perusahaan.

Hasil penelitian ini tidak konsisten dengan penelitian Rahayu \& Rahayu (2013) serta Deitiana (2015) yang menyatakan bahwa kapitalisasi pasar tidak berpengaruh pada pengungkapan CSR, namun hasil penelitian ini konsisten dengan penelitian yang dilakukan oleh Indraswari \& Mimba (2017), Sufian (2012) dan Oktavila (2019) yang menyatakan bahwa kapitalisasi pasar berpengaruh pada luas pengungkapan CSR.

Hipotesis ketiga $\left(\mathrm{H}_{3}\right)$ menyatakan bahwa kepemilikan saham publik berpengaruh positif pada pengungkapan CSR. Berdasarkan hasil penelitian 
menunjukkan variabel kepemilikan saham publik tidak berpengaruh pada pengungkapan CSR. Hasil ini menolak hipotesis ketiga $\left(\mathrm{H}_{3}\right)$. Hal ini menunjukkan bahwa besar kecilnya kepemilikan saham publik yang diukur melalui rasio dari jumlah kepemilikan lembar saham yang dimiliki publik terhadap total saham perusahaan tidak akan mempengaruhi luas pengungkapan CSR.

Hasil penelitian ini bertentangan dengan penelitian yang dilakukan oleh Sugiarto \& Mas'ud (2016), Evandini \& Darsono (2014), Rahayu \& Anisyukurlillsah (2015), Gunawan et al., (2018) yang menyatakan bahwa kepemilikan saham publik berpengaruh pada pengungkapan tanggung jawab sosial perusahaan. Hasil penelitian ini juga tidak mendukung teori stakeholder. Hal ini dikarenakan, kepemilikan saham publik terdiri dari gabungan beberapa pemegang saham dengan skala kecil yang menyebabkan kurangnya perhatian perusahaan terhadap pemegang saham publik. Prosentase saham yang kecil juga mengindikasikan bahwa tidak ada pengaruh kuat dari investor untuk terlibat pada pengungkapan CSR karena semakin kurangnya partisipasi yang diberikan perusahaan kepada investor (Santoso et al., 2017).

Hasil penelitian ini konsisten dengan penelitian yang dilakukan oleh Rahmadhana et al., (2015), Santoso et al., (2017) dan Andriana \& Anggara (2019) yang menyatakan bahwa kepemilikan saham publik tidak berpengaruh pada pengungkapan tanggung jawab sosial perusahaan.

\section{SIMPULAN}

Berdasarkan hasil analisis dan pengujian yang telah dilakukan, maka dapat disimpulkan sebagai berikut. 1) Profitabilitas berpengaruh positif pada luas pengungkapan corporate social responsibility. 2) Kapitalisasi pasar berpengaruh positif pada luas pengungkpan corporate social responsibility. 3) Kepemilikan saham publik tidak berpengaruh pada luas pengungkapan corporate social responsibility. Rendahnya persentase kepemilikan saham publik pada perusahaan sampel menyebabkan kurangnya perhatian perusahaan terhadap pemegang saham publik. Rendahnya persentase kepemilikan saham publik juga menyebabkan pemegang saham publik tidak memiliki pengaruh yang kuat untuk turut menekan perusahaan dalam melakukan kebijakan pengungkapan informasi tanggung jawab sosial.

Bagi manajemen perusahaan diharapkan untuk lebih mengungkapkan kegiatan-kegiatan yang berhubungan dengan tanggung jawab sosialnya secara lebih lengkap dan rinci, sebagai bentuk jaminan pada pihak eksternal khususnya stakeholder dan pemangku kepentingan lainnya. Diharapkan pada penelitian selanjutnya untuk mempertimbangkan jumlah sampel yang lebih besar atau menggunakan sampel penelitian selain perusahaan perkebunan untuk dapat mengetahui perbandingan terkait pengungkapan CSR pada perusahaan lain.

\section{REFERENSI}

Andriana, I. K. G. S., \& Anggara, I. W. G. W. P. (2019). Pengaruh Ukuran Perusahaan, Profitabilitas, Leverage Dan Kepemilikan Saham Publik Pada Pengungkapan Corporate Social Responsibility. E-Jurnal Akuntansi, 29(1), 111-127.

Branco, M. C., \& Rodrigues, L. L. (2008). Factors influencing social responsibility 
disclosure by Portuguese companies. Journal of Business Ethics, 83, 685-701. https:// doi.org/10.1007/s10551-007-9658-z

Budiman, N. A. (2015). Faktor-Faktor yang Mempengaruhi Pengungkapan Tanggung Jawab Sosial. JRAMB, Prodi Akuntansi, Fakultas Ekonomi, UMB Yogyakarta, 1(1), 14-34.

Deitiana, T. (2015). The Determinant of CSR Disclosure of Mining Industry Listed in Indonesia Stock Exchange. Asian Business Review, 5(3), 141-148. https:// doi.org/10.18034/abr.v5i3.664

Ebiringa, O. T., Yadirichukwu, E., Chigbu, E. E., \& Ogochukwu, O. J. (2013). Effect of Firm Size and Profitability on Corporate Social Disclosures: The Nigerian Oil and Gas sector in Focus. British Journal of Economics, Management \& Trade, 3(4), 563-574.

Evandini, C., \& Darsono. (2014). Faktor-faktor yang Berpengaruh Terhadap Pengungkapan Tanggung Jawab Sosial Perusahaan Pada Perusahaan Manufaktur yang Terdaftar di BEI. Diponegoro Journal of Accounting, 3(3), 111.

Fariati, \& Segoro, W. (2013). Pengaruh Ukuran Entitas, Profitabilitas, Leverage, Dan Ukuran Dewan Komisaris Terhadap Pengungkapan Tanggung Jawab Sosial Pada Entitas Industri Dasar Dan Kimia Yang Terdaftar Di Bei Periode 2010-2011. Proceeding PESAT (Psikologi, Ekonomi, Sastra, Arsitektur \& Teknik Sipil), 5, 278-286.

Felicia, M., \& Rasmini, N. K. (2015). Faktor-Faktor Yang Mempengaruhi Pengungkapan Corporate Social Responsibility Pada Perusahaan yang Terdaftar di BEI. E-Jurnal Akuntansi Universitas Udayana, 12(2), 143-153.

Gunawan, A., Puntoro, H. R., \& Pakolo, R. P. (2018). the Effect of Profitability, Company Age, and Public Ownership on Corporate Social Responsibility Disclosure. Jurnal Akuntansi Trisakti, 5(2), 291-298. https:/ / doi.org/10.25105/jat.v5i2.4860

Hackston, D., \& Milne, Markus, J. (1996). Some determinants of socialand environmental disclosuresin New Zealand companies. Accounting, Auditing $\mathcal{E}$ Accountability Journal, 9(1), 77-108.

Haniffa, R. M., \& Cooke, T. E. (2005). The impact of culture and governance on corporate social reporting. Journal of Accounting and Public Policy, 24(5), 391430. https://doi.org/10.1016/j.jaccpubpol.2005.06.001

Hapsoro, D., \& Sulistyarini, R. D. (2019). The Effect of Profitability and Liquidity on CSR Disclosure and its Implication to Economic Consequences. The Indonesian Accounting Review, 9(2), 143-154.

Indraswari, G. A. D., \& Astika, I. B. P. (2014). Gusti Ayu Dyah Indraswari mengembangkan Corporate Sosial Responsibility ( CSR ). Diterapkannya CSR bukan. E-Jurnal Akuntansi Universitas Udayana, 9(3), 816-828.

Indraswari, I. G. A. L., \& Mimba, N. P. S. H. (2017). Pengaruh Profitabilitas, Pertumbuhan Perusahaan, Kapitalisasi Pasar dan Kepemilikan Publik pada Tingkat Pengungkapan CSR. E-Jurnal Akuntansi Universitas Udayana, 20(2), 1219-1248.

Jewell, J. J., \& Mankin, J. A. (2011). What Is Your Roa? an Investigation of the Many Formulas for Calculating Return on Assets. Academy of Educational Leadership Journal, 15(Special Issue), 79-91. 
Kusumawardani, I., \& Sudana, I. P. (2017). Faktor-faktor yang Mempengaruhi Pengungkapan Corporate Social Responsibility. E-Jurnal Akuntansi Universitas Udayana, 19(1), 741-770.

Lindawati, A. S. L., \& Puspita, M. E. (2015). Corporate Social Responsibility: Implikasi Stakeholder dan Legitimacy Gap dalam Peningkatan Kinerja Perusahaan. Jurnal Akuntansi Multiparadigma, 6(1), 157-174.

Mudjiyanti, R., \& Maulani, S. S. (2017). Pengaruh Likuiditas dan Profitabilitas Terhadap Pengungkapan Corporate Social Responsibility pada Perusahaan Terdaftar di Bursa Efek Indonesia. Jurnal Manajemen Dan Bisnis MEDIA EKONOMI, 17(1), 7-12.

Nur, M., \& Priantinah, D. (2012). Analisis Faktor-Faktor Yang Mempengaruhi Pengungkapancorporate Social Responsibility Di Indonesia (Studi Empiris Pada Perusahaan Berkategori High Profile Yang Listing Di Bursa Efek Indonesia). Jurnal Nominal, Barometer Riset Akuntansi Dan Manajemen, 1(1), 2234.

Oktavila, \& Erinos, N. R. (2019). Pengaruh Kapitalisasi Pasar dan Good Corporate Governance Terhadap Pengungkapan Corporate Social Responsibility (Studi Empiris Pada Perusahaan Manufaktur Yang Terdaftar di Bursa Efek Indonesia Tahun 2015-2017). Jurnal Eksplorasi Akuntansi, 1(3), 1184-1199.

Prakasa, S., \& Astika, I. B. P. (2017). Pengaruh Leverage, Profitabilitas, dan Kepemilikan Manajemen Pada Corporate Social Responsibility Disclosure Perusahaan Pertambangan. E-Jurnal Akuntansi Universitas Udayana, 18(1), 189-215.

Rahayu, I., \& Rahayu, D. F. (2013). Determinan Pengungkapan Tanggungjawab Sosial Di Negara Berkembang: Studi Empiris Perusahaan Manufaktur Di Indonesia. Jurnal Ekonomi Dan Bisnis Islam, 8(1), 83-92.

Rahayu, P., \& Anisyukurlllah, I. (2015). Pengaruh Kepemilikan Saham Publik, Profitabilitas Dan Media Terhadap Pengungkapan Tanggung Jawab Sosial. Accounting Analysis Journal, 4(3), 1-9.

Rahmadhana, S., Nafsiah, S. N., \& Darmawan, J. (2015). Faktor-Faktor yang Mempengaruhi Pengungkapan Informasi Sosial Laporan Tahunan pada Perusahaan Manufaktur Sektor Industri Barang dan Konsumsi yang Listed di BEI. Conference on Management and Behavioral Studie, 1-18.

Rifqiawan, R. A. (2015). Pengaruh Profitabilitas Dan Kapitalisasi Pasar Terhadap Nilai Emiten Jakarta Islamic Index. Economica: Jurnal Ekonomi Islam, 6(2), 2136. https://doi.org/10.21580/economica.2015.6.2.791

Rindawati, M. W., \& Asyik, N. F. (2015). Pengaruh Profitabilitas, Ukuran Perusahaan, Leverage, dan Kepemilikan Publik Terhadap Pengungkapan Corporate Social Responsibility (CSR). Jurnal Ilmu E Riset Akuntansi, 4(6), 115.

Riswari, D. A., \& Cahyonowati, N. (2012). Pengaruh Corporate Social Responsibility Tehadap Nilai Perusahaan Dengan Corporate Governance Sebagai Variabel Moderating : Studi Pada Perusahaan Publik Non Finansial Yang Tercatat Di Bursa Efek Indonesia. Diponegoro Journal of Accounting, 1(1), $1-12$.

Rokhlinasari, S. (2015). Teori -Teori dalam Pengungkapan Informasi Corporate Social Responbility Perbankan. Jurnal Kajian Ekonomi Dan Perbankan Syari'ah, 
$7(1), 1-11$.

Santoso, A. D., Utomo, S. W., \& Astuti, E. (2017). Pengaruh kepemilikan saham publik, ukuran perusahaan dan profitabilitas terhadap corporate social responsibility disclosure (studi pada perusahaan perbankan yang terdaftar di bei periode 2012-2015. Forum Ilmiah Pendidikan Akuntansi, 9(1), 836-854.

Sufian, M. A. (2012). Corporate Social Responsibility Disclosure in Bangladesh. Global Journal of Management and Business Research, 12(14), 149-154.

Sugiarto, M., \& Mas'ud, I. (2016). Pengaruh Pengungkapan Corporate Social Responsibility dan Good Corporate Governance terhadap Return Saham (Studi Empiris pada Perusahaan Sektor Industri Dasar dan Kimia yang Terdaftar di BEI). Artikel Ilmiah Mahasiswa, x, 1-13.

Wakidi, R. H., \& Siregar, H. S. (2011). Pengaruh Sisi Internal Dan Eksternal Perusahaan Terhadap Pengungkapan Tanggung Jawab Sosial Pada Perusahaan Manufaktur Yang Terdaftar Di BEI. Jurnal Ekonom, 14(4), 180-190.

Wulandari, A. A. A. I., \& Sudana, I. P. (2018). Pengaruh Profitabilitas, Kepemilikan Asing, Kepemilikan Manajemen, dan Leverage Pada Intensitas Pengungkapan Corporate Social Responsibility. E-Jurnal Akuntansi Universitas Udayana, 22(2), 1445-1472.

Yanti, N. K. A. G., \& Budiasih, I. G. A. N. (2016). Pengaruh Profitabilitas, Leverage Dan Ukuran Perusahaan Pada Pengungkapan Corporate Social Responsibility. E-Jurnal Akuntansi Universitas Udayana, 17(3), 1752-1779. 